\title{
Growth and yield of tomato (Solanum lycopersicum L.) as influenced by different soil organic amendments and types of cultivation
}

\author{
Ana Linda G. Gorme', Zenaida C. Gonzaga'", Othello B. Capuno', Jessie C. Rom', \\ Sandra McDougall ${ }^{2}$, Adam D. Goldwater ${ }^{3}$ and Gordon S. Rogers ${ }^{3}$
}

\begin{abstract}
Tomato is one of the most profitable crops in the Philippines and is extensively cultivated throughout the world. However, its production faces different pest and disease problems, particularly bacterial wilt which greatly reduces yield. Two separate studies were conducted simultaneously in a single factor experiment arranged in randomized complete block design (RCBD) with three (3) replications. The studies were conducted to evaluate the effects of the different soil organic amendments on the growth and yield of tomato in the open field (Study I) and under protective structure (Study II) with the following treatments: control, cabbage waste, carbonized rice hull, chicken dung, hagonoy, wedelia, and wild sunflower. Protective structure grown plants had better protection against detrimental heavy rain and strong light intensity, thus had better performance in terms of lower bacterial wilt infection and weed incidence, higher percentage survival, enhanced flowering, and a higher yield than those grown in the open field. On the other hand, only the weight of marketable fruits and total yield were enhanced by the application of the different soil organic amendments. All amendments had similar effects but were superior than the control. Protected cultivation gave a higher net return than the open field. In particular, sunflower amended plants under structure were the most profitable, by almost 8 times compared to the open field.
\end{abstract}

Keywords: Bacterial wilt, Isothiocyanates, wedelia, devil weed, natural suppression

\section{INTRODUCTION}

Tomato, scientifically known as Solanum lycopersicum, is extensively cultivated throughout the world. It is considered to be one of the most profitable crops in the Philippines and the second most important fruit vegetable in the

'Visayas State University (VSU), Philippines

${ }^{2}$ Department of Primary Industries (DPI), Australia

${ }^{3}$ Applied Horticultural Research (AHR), Australia

* Corresponding Author. Address: Department of Horticulture, Visayas State University, Visca, Baybay City, Leyte, 6521-A Philippines; Email:zcgonzaga@yahoo.com

DOI: $10.32945 /$ atr39sb9.2017 


\section{Growth and yield of tomato}

country after eggplant (Altoveros \& Borromeo 2007). It was reported that 4.8 million hectares of tomato were planted worldwide with a production reaching 161.8 million tons in the year 2012 (FAOSTAT 2012). Moreover, the Philippines produced about 214.6 thousands metric tons of tomato from 16.7 thousand hectares (BAS 2015). Consumption of tomatoes by Filipinos continues to increase due to its wide variety of uses and nutritional value. Tomatoes are rich in minerals, vitamins, essential amino acids, sugars, antioxidants and dietary fibers, which all contribute to a healthy and well-balanced diet.

However, tomato production in the Philippines faces many constraints. Tomato is susceptible to a number of diseases such as fusarium wilt, root rot, verticillium, bacterial wilt and many others which reduce yield and quality, and in some cases results in death of the plant. Among the soil borne diseases, tomato is highly susceptible to bacterial wilt caused by Ralstonia solanacearum, which is one of the most important and widely distributed plant pathogenic bacteria in the tropical, subtropical and warm temperate climates of the world (Hayward 1991). It causes bacterial wilt disease on over 200 plant species in 50 families (Hayward 2000) and remains the major biotic factor limiting growth and development of several important solanaceous crops including potato, tomato, eggplant, pepper and tobacco (Anith et al 2004). In addition, bacterial wilt is a serious disease in the ACIAR-ICM (Australian Centre for International Agricultural Research-Integrated Crop Management) field site. This field site was severely contaminated with the pathogen that infects solanaceous and cucurbits as experienced by many researchers (Abrantes 2013, Borines et al 2016, Dimabuyu et al 2016, Gonzaga et al 2013, Lacostales 2015, Sumalinog 2015, Tuyan 2015).

In order to control diseases such as bacterial wilt in a sustainable way, the use of soil organic amendments can be considered. These not only add nutrients to the soil, but can also control soil borne diseases.

Application of soil organic amendments is a traditional practice for maintaining soil health and fertility that results in higher yield and quality of crops. They contain macro and micro nutrients, vitamins, growth promoting hormones like IAA, GA, as well as beneficial microorganisms (Sreenivasa et al 2010). In addition, amending agricultural soils with organic matter increases natural suppression of soil-borne pathogens through increasing beneficial microbes which creates biological competition and antagonism, and improves physicochemical of the soil (Janvier et al 2007). Among the soil organic amendments that have been noted to improve soil properties as well as be effective in supressing soil borne diseases and pathogens are wedelia (Holopainen 2004), devil weed (Ana \& Sugha 2011), cabbage waste (Brown \& Morra 1997), chicken dung (Gonzales et al 1993), sunflower (Agustin 2007) and carbonized rice hull (Gregon et al 2000).

While the growing of vegetables under protective structure had been reported to not just increase the yield of vegetable crops, but also preventive measures to pests are important to consider (Gonzaga et al 2013). The present study aimed to investigate the effect of different organic soil amendments on tomato grown under protective structures and the open field. 
Gonzaga et al

\section{MATERIALS AND METHODS}

\section{Site Description}

This study was conducted in the Australian Centre for International Agricultural Research-Integrated Crop Management project site of the Department of Horticulture, Visayas State University. The area was known to have bacterial wilt contamination as determined by Philippine Diagnostic Disease Laboratory (PDDL) of the University as determined by Ooze test of previously planted tomatoes and Immunostrip diagnostic kit.

\section{Protective Structure}

A house-type protective structure with curved bamboo roofing was used in this study. This structure has open sides for good ventilation. It has an inner area of $200 \mathrm{~m}^{2}$ ie, $5 \mathrm{~m} \times 40 \mathrm{~m}$. The roof was covered with $0.002 \mathrm{~mm}$ UV-treated plastic and stands $4 \mathrm{~m}$ high.

\section{Experimental Design and Treatments}

Two separate studies were conducted simultaneously under the protective structure and open field. Each was designed as a single factor experiment arranged in randomized complete block design (RCBD) with three replications. The organic amendments used as treatments were cabbage waste, carbonized rice hull (CRH), chicken dung, hagonoy (Chromolaea odorata), wedelia (Wedelia tribolata), wild sunflower (Tithonia diversifolia), and control which had no organic amendments. Except for $\mathrm{CRH}$ and chicken dung, the different plant materials were shredded fresh, distributed evenly and incorporated into the designated plots at the rate of $1 \mathrm{~kg}$ per $\mathrm{m}^{2}$. Tomato seedlings were transplanted one week after application of amendments.

\section{Cultural Management}

The land preparation included plowing and harrowing twice at a gap of one week. Soil samples were taken and submitted to laboratory located within the university for nutrient analysis. Fertilizer application of $90-60-60 \mathrm{~kg} \mathrm{~N}, \mathrm{P}_{2} \mathrm{O}_{5}, \mathrm{~K}_{2} \mathrm{O}$ per hectare using complete (16-16-16 NPK) and calcium nitrate (19\% Ca \& 15.5\% $\mathrm{NO}_{3}$ ) were applied at planting, basally. One week after transplanting, calcium nitrate was drenched at a concentration of $250 \mathrm{~g}$ per $50 \mathrm{~L}$ of water, with $150 \mathrm{~mL}$ applied per plant. Watering was through a drip hose. Plants were monitored for pest invasion and appropriate control measures implemented with the help of crop protection experts of the university. Trellis was installed by tie-to-hold technique using plastic string. Weeding was done at weekly intervals starting a week after transplanting and finished within a month. Harvesting was by hand on every 2-3 days with a total of 8 harvesting period. Fruit were picked at mature green and breaker stage. 
Growth and yield of tomato

\section{Data Analysis}

Data gathered was analyzed by Analysis of variance (ANOVA) using Statistical Tool for Agricultural Research (STAR) software version 2.0.1 developed by International Rice Research Institute (IRRI) biometrics group. The means were compared by Tukey's honest significant difference (HSD) at $5 \%$ level of significance.

\section{RESULTS AND DISCUSSION}

\section{Horticultural Characteristics}

Plants grown in the open field and under structures were of similar height within the first two weeks of transplanting (Figure 1). Significant differences were noted starting the $3^{\text {rd }}$ week from transplanting to the $7^{\text {th }}$ week, where protective structure grown plants were consistently taller than those in the open field. This study supports the report of Halem and Islam (2013), that plants grown under protective structures were taller compared to plants grown in the open field. Furthermore, the study is consistent with the report of Lacostales (2015) and Lusanta (2016) who found considerably taller plants were obtained when grown under a protective structure than the open field due to decreased light intensity which was filtered by the plastic cover (Rylski \& Spigelman 1986). Plant height increases as a result of shading stimulated auxin accumulation (Berg 2008), which enhances cell elongation and minimizes the growth of lateral shoots (Chen 2001).

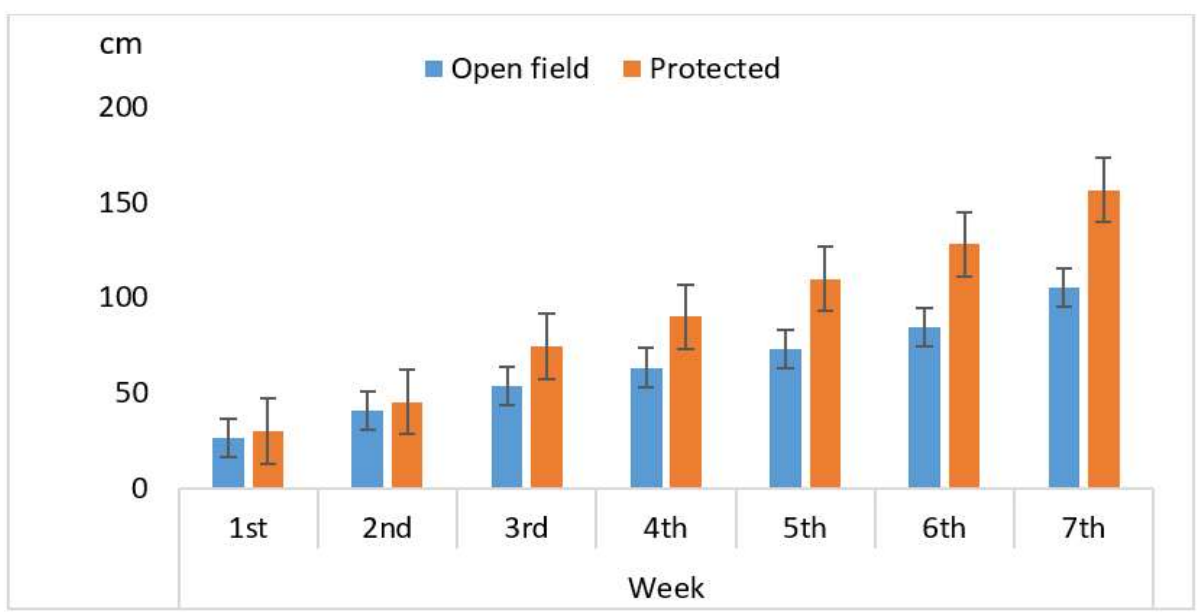

Figure 1. Weekly plant height $(\mathrm{cm})$ of tomato (Solanum lycopersicum L.) grown in the open field and protective structure

\section{Survival and Wilt Incidence}

A significantly higher bacterial wilt infection of $67.5 \%$ was recorded in plants grown in the open field compared to only $28.17 \%$ under the protective structure (Figures $3 \& 4$ ). This was mainly because tomato in the open field was exposed to adverse environmental conditions such as heavy rain which favors the growth of 
the disease (Figures $5 \& 6$ ). In the open field, heavy rain leaves surface water on the plant, which is conducive to the motile bacterial wilt pathogen $R$. solanacearum. Surface water run-off in other areas of the field also favors the dissemination of the water borne inoculum to other plants. Inside the protective structures, moisture extremes were regulated, which is unfavorable for soil-borne pathogens such as $R$. solanacearum.

Percent survival under the protective structure was more than twice that of the open field (Figure 2). The significantly higher survival of $71.8 \%$ of plants grown under the protective structure could be ascribed to the protection offered by the structure. Protective structures provide shelter to vegetable crops from abiotic and biotic stresses (Palada 2011). This result supports the findings of Gonzaga et al (2013), where the incidence of diseases, particularly bacterial wilt, was generally higher in the open field thereby lower survival than under the protective structure due to detrimental effects of rain. On the other hand, the different soil amendments had comparable effects. However survival was higher where plants had soil amendments applied.

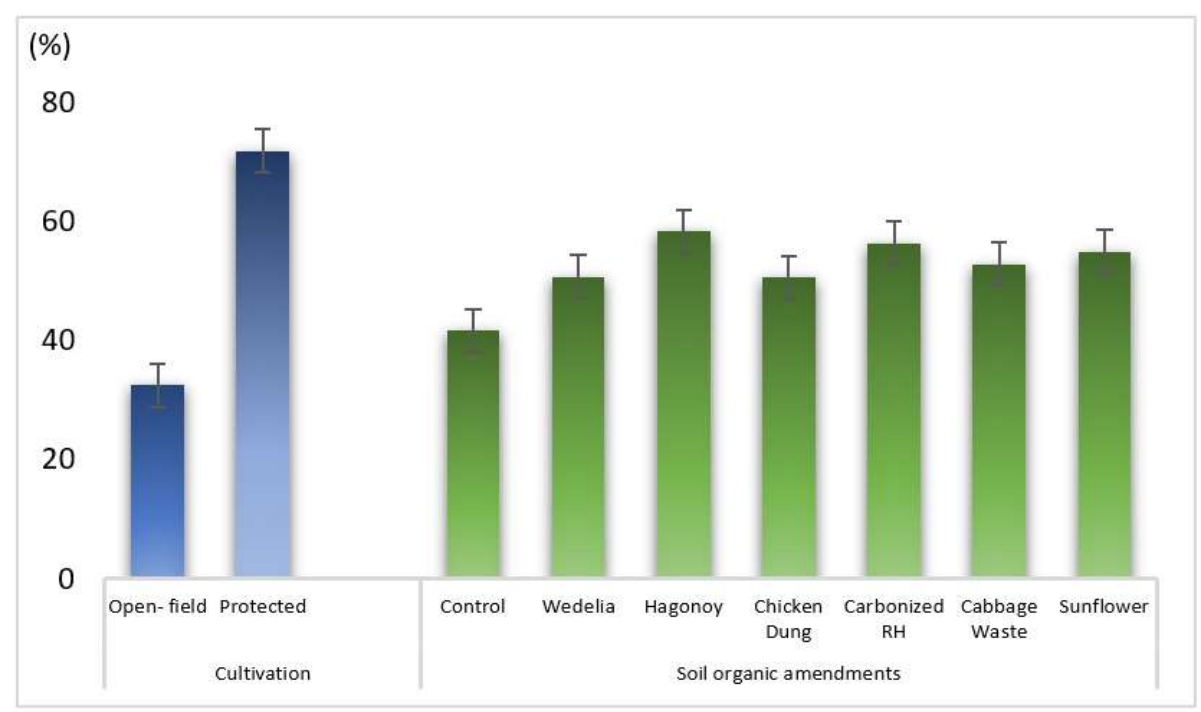

Figure 2. Percent survival of tomato (Solanum lycopersicum L.) grown in the open field and protective structure as influenced by different soil organic amendments 
Growth and yield of tomato

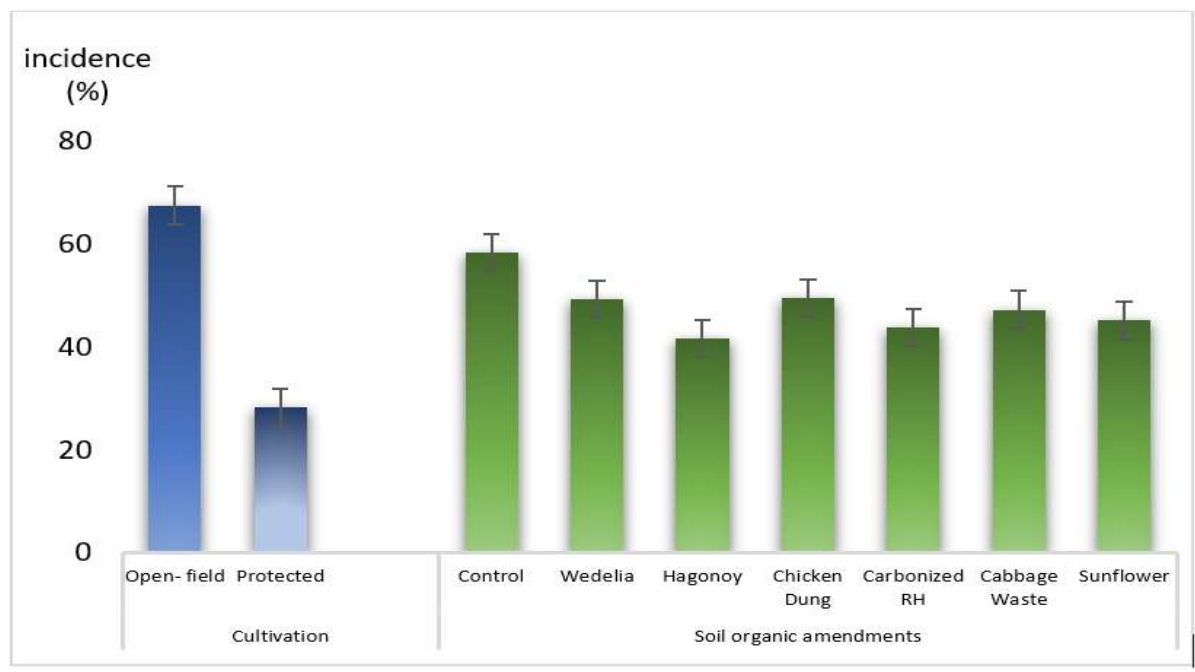

Figure 3. Percent Bacterial wilt incidence of tomato (Solanum lycopersicum L.) grown in the open field and protective structure as influenced by different soil organic amendments

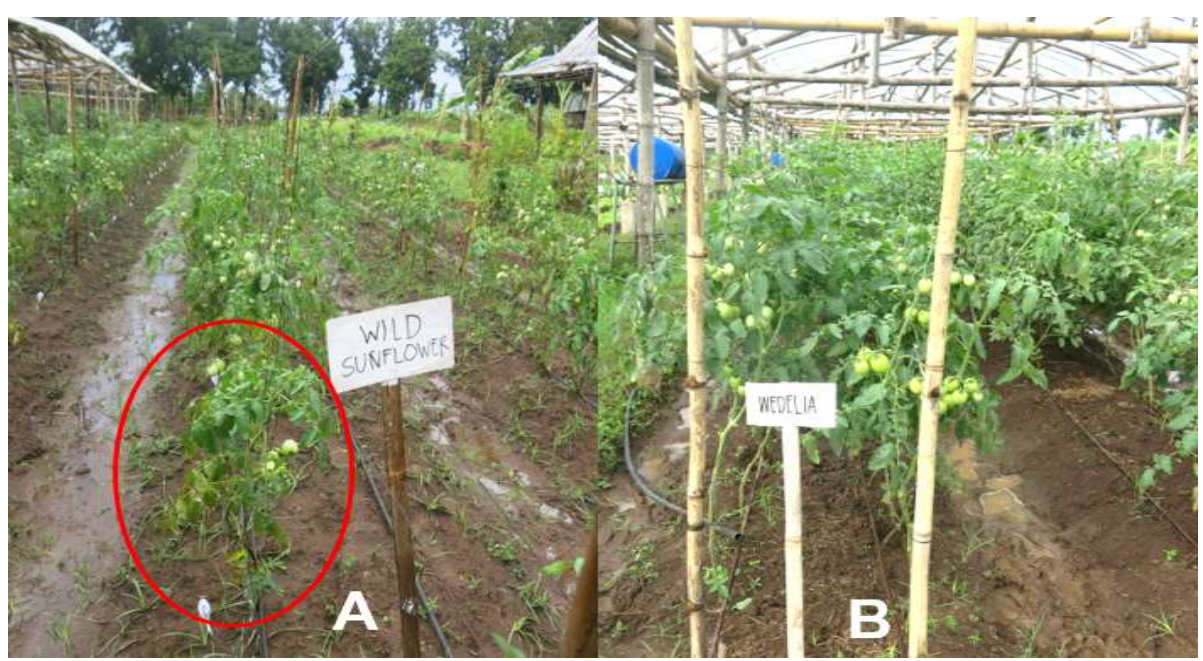

Figure 4. Open field grown tomato showing signs of bacterial wilt incidence and lower survival (A) than under protective structure (B) 


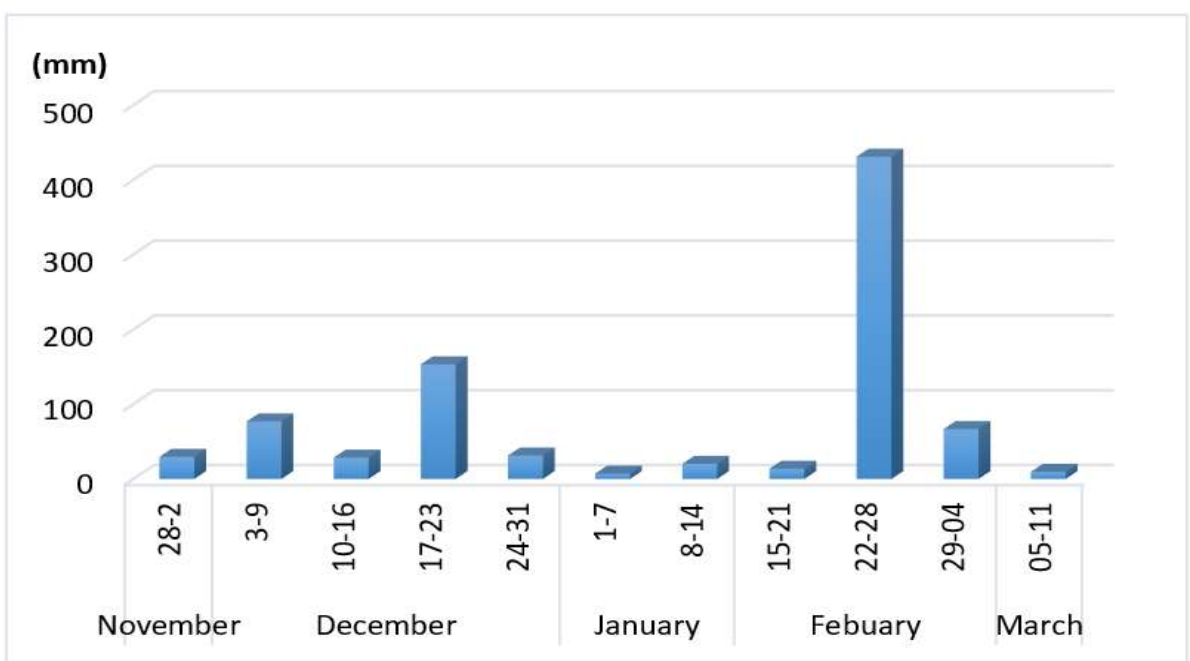

Figure 5. Total weekly rainfall $(\mathrm{mm})$ from November to March 2016 taken from PAG-ASA meteorological station, VSU, Visca, Baybay City, Leyte

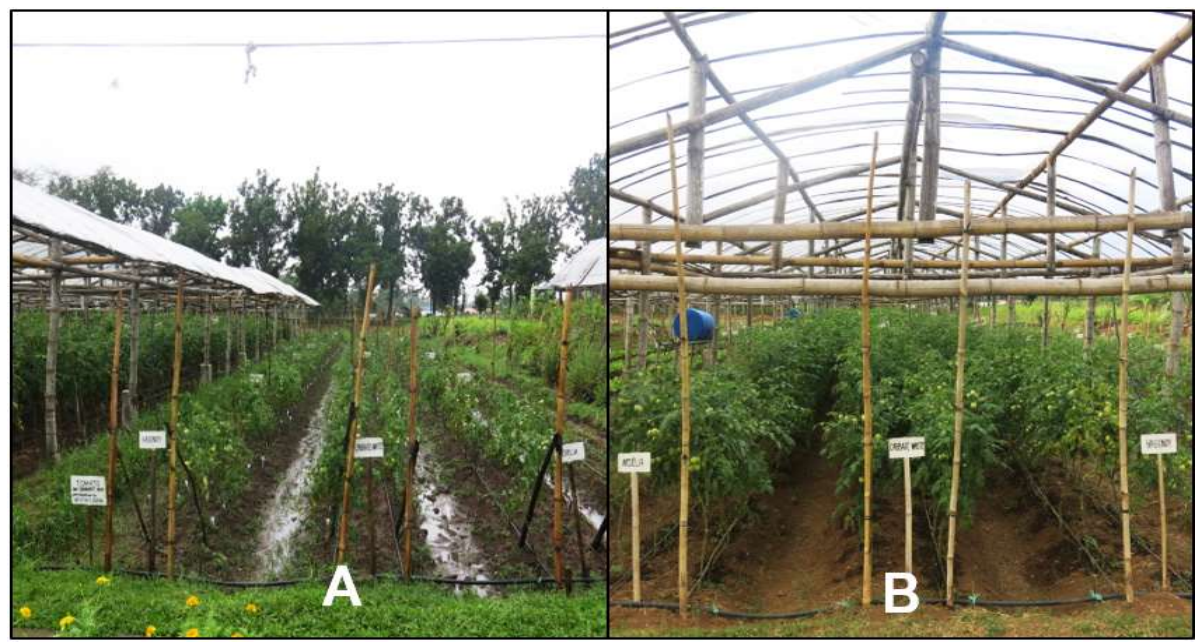

Figure 6. Open field grown tomato with excess water after rain (A) and controlled watering of tomato plants grown under protective structures (B)

\section{Weed Incidence}

Protected cropping had significantly lower weed weight compared to the open field (Figures $7 \& 8$ ). The open field cultivation increased weed weight by $394 \%$ due to fast growth and availability of water. This supports the study of Sumalinog (2015) who obtained heavier and more weeds in the open field than in the protective structure, due to the available moisture that favors the germination of weeds and faster distribution of weed seeds in the area. 
Growth and yield of tomato

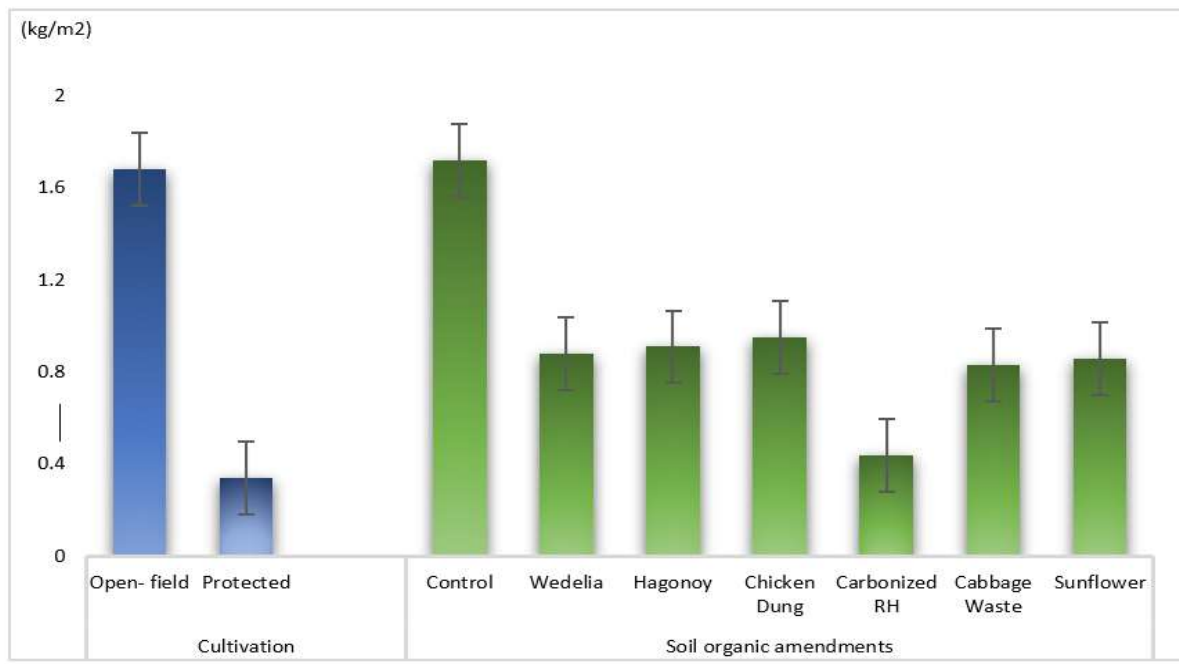

Figure 7. Weed dry weight of tomato (Solanum lycopersicum L.) as influenced by different soil organic amendments grown in the open field and protected cultivation

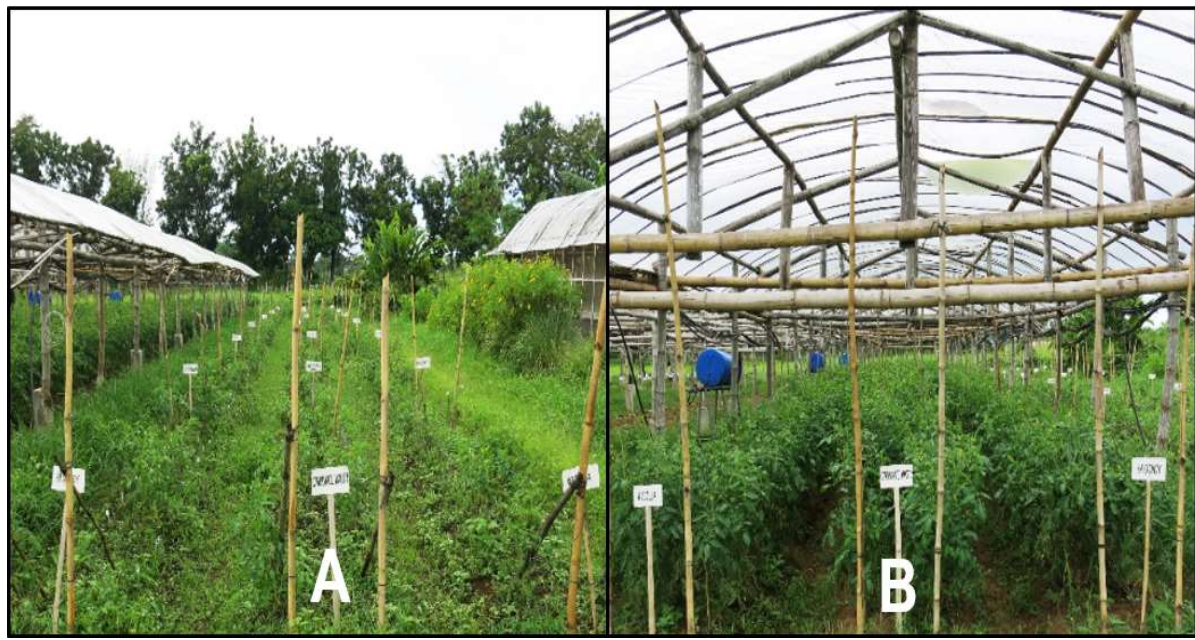

Figure 8. Higher weed incidence of tomato (Solanum lycopersicum L.) grown in the open field (A), than in protected cultivation (B)

All soil organic amendments effectively controlled weed growth. The amended plots had $53 \%$ less weed weight than the unamended plots. This result could be ascribed to the reports that some amendment species have toxic effects on the growth of some plants, such as the green manure of Brassicaceae plants (Brassica juncea L., Sinapsis alba L.: Norsworthy et al (2005)), sunflower (Helianthus annus L.), dhaincha (Sesbania aculeata Poiret: Om et al (2002)), or red clover (Trifolium pratense L.: Ohno et al (2000)). 
Gonzaga et al

\section{Yield and Yield Components}

Yield of tomato grown under protective structure was significantly higher than the open field. Yield per plot was 5 times higher in the protective structure than in the open field (Table 1). Bigger and heavier fruits were produced under protected cultivation than in open field. The low yields in the open field were due to the heavy rains and excessive water experienced resulting in a low survival rate. Result is in consonance with the reports of Lusanta, (2016), Lacostales (2015), Sumalinog, (2015), and Tuyan (2015), who all found higher yields under protective structures than in the open field. The increased yield under protective structures is widely known to be the result of several favorable conditions. These include reduced moisture, especially on the leaves which reduces susceptibility to diseases, fruits protected from direct contact with soil, reduced weed growth, more moderate soil and air temperatures, and reduced leaching of nutrients from soils (De La Pena \& Hughes 2007).

Table 1. Yield and yield components of tomato (Solanum lycopersicum L.) grown in the open field and protective structure as influenced by different soil organic amendments

\begin{tabular}{|c|c|c|c|c|c|c|c|}
\hline \multirow[t]{2}{*}{ Treatments } & \multicolumn{2}{|c|}{$\begin{array}{l}\text { Marketable fruit } \\
\quad\left(\mathrm{kg} \text { per } 5 \mathrm{~m}^{2}\right)\end{array}$} & \multicolumn{2}{|c|}{$\begin{array}{c}\text { Non -Marketable } \\
\text { fruit } \\
\left(\mathrm{kg} \text { per } 5 \mathrm{~m}^{2}\right)\end{array}$} & \multicolumn{2}{|c|}{ Fruit diameter $(\mathrm{cm})$} & \multirow{2}{*}{$\begin{array}{l}\text { Total } \\
\text { yield } \\
\left(\mathrm{t} \mathrm{ha}^{-1}\right)\end{array}$} \\
\hline & Number & Weight & Number & Weight & Polar & Equatorial & \\
\hline \multicolumn{8}{|l|}{ Type of Cultivation } \\
\hline Open field & $168 a$ & $4.99 b$ & 4.95 & $0.77 \mathrm{~b}$ & $4.31 b$ & $3.98 b$ & $11.51 \mathrm{~b}$ \\
\hline Protected & $1050 \mathrm{~b}$ & $25.94 a$ & 9.52 & $2.42 a$ & $4.72 a$ & $4.55 a$ & $56.71 \mathrm{a}$ \\
\hline \multicolumn{8}{|l|}{ Soil amendments } \\
\hline Control & 508 & $10.60 \mathrm{~b}$ & 6.17 & 1.07 & 4.55 & 4.27 & $23.36 b$ \\
\hline Wedelia & 595 & $15.94 a$ & 6.83 & 1.70 & 4.62 & 4.27 & $35.28 a$ \\
\hline Hagonoy & 500 & $15.64 a$ & 8.17 & 1.77 & 4.45 & 4.31 & $34.83 a$ \\
\hline Chicken Dung & 669 & $15.39 a$ & 7.67 & 1.74 & 4.48 & 4.31 & $34.26 a$ \\
\hline Carbonized RH & 726 & $17.31 \mathrm{a}$ & 7.83 & 1.57 & 4.58 & 4.26 & $37.76 a$ \\
\hline Cabbage Waste & 583 & $15.98 \mathrm{a}$ & 6.50 & 1.71 & 4.50 & 4.14 & $35.37 \mathrm{a}$ \\
\hline Sunflower & 584 & $17.39 a$ & 7.50 & 1.57 & 4.46 & 4.30 & $37.92 a$ \\
\hline
\end{tabular}

Means within the same column in a block followed by a common letters and or no letter designation are not significantly different from each other at $5 \%$ level using least Significant difference

Among the yield and yield components, only the marketable weight per plot $(\mathrm{kg}$ per $\left.5 \mathrm{~m}^{2}\right)$ and total yield $\left(\mathrm{t} \mathrm{ha} \mathrm{a}^{-1}\right)$ were significantly affected by the soil amendments used. All amended plants had a significantly higher yield than no amendment. This could be due to the claim that organic amendments not only improve soil conditions, but also soil-water-plant relations, by modifying soil bulk density, total porosity, and importantly provide nutrients. Consequently, amendments increase plant growth, yield and water use efficiency (Obi \& Ebo 1995). In addition, several reports mentioned that application of different organic soil amendments can increase the yield of crops (Song 2015) including lettuce, (Kimpinski 2003) potato, (Ghorban 2008) and tomato. Other parameters like the number of marketable fruits, number and weight of non-marketable fruits and fruit size were not affected by the soil amendments used. 
Growth and yield of tomato

\section{Cost and Return Analysis}

The net returns of tomatoes under protected cropping were comparatively higher than those grown in open field (Table 2). Although protected cropping had higher expenses than open field due to cost of structure, higher net return was highly associated by increased yield in this type of cultivation. Plants applied with sunflower gave the highest net return in protected cropping and wedelia in open field. Net return of sunflower under protected cultivation was PHP41, 452 per $200 \mathrm{~m}^{2}$ ie, $73 \%$ increase on unamended plants in the same cultivation. In open field, wedelia gave PHP6, 072 ie, $569 \%$ increase than unamended.

Table 2. Estimates on the cost and return of tomato production grown in the open field and under protective structure as influenced by different organic soil amendments

\begin{tabular}{|c|c|c|c|c|}
\hline Treatments & $\begin{array}{c}\text { Yield } \\
\left(\mathrm{kg} / 200 \mathrm{~m}^{2}\right)\end{array}$ & $\begin{array}{c}\text { Gross } \\
\text { Income }(\nexists)\end{array}$ & $\begin{array}{c}\text { Total expenses } \\
\text { (尹) }\end{array}$ & $\begin{array}{l}\text { Net return } \\
\text { (P) }\end{array}$ \\
\hline \multicolumn{5}{|l|}{ Open Field } \\
\hline Control & 115.20 & $4,608.00$ & $3,699.88$ & 908.12 \\
\hline Wedelia & 246.80 & $9,872.00$ & $3,799.88$ & $6,072.12$ \\
\hline Hagonoy & 239.60 & 9584.00 & $3,799.88$ & $5,784.12$ \\
\hline Chicken dung & 130.40 & 5216.00 & $4,099.88$ & $1,116.12$ \\
\hline Carbonized RH & 249.20 & 9968.00 & $4,099.88$ & $5,868.12$ \\
\hline Cabbage waste & 198.00 & 7920.00 & $3,799.88$ & $4,120.12$ \\
\hline Sunflower & 218.40 & 8736.00 & $3,799.88$ & $4,936.12$ \\
\hline \multicolumn{5}{|c|}{ Protected cultivation } \\
\hline Control & 732.80 & $29,312.00$ & $5,343.33$ & $23,968.67$ \\
\hline Wedelia & 1028.80 & $41,152.00$ & $5,443.33$ & $35,708.67$ \\
\hline Hagonoy & 1012.00 & $40,480.00$ & $5,443.33$ & $35,036.67$ \\
\hline Chicken dung & 1100.80 & $44,032.00$ & $5,743.33$ & $38,288.67$ \\
\hline Carbonized RH & 1135.20 & $45,408.00$ & $5,743.33$ & $39,664.67$ \\
\hline Cabbage waste & 1089.40 & $43,216.00$ & $5,443.33$ & $37,772.67$ \\
\hline Sunflower & 1172.40 & $46,896.00$ & $5,443.33$ & $41,452.67$ \\
\hline
\end{tabular}

Gross income $=$ Based on current market price $(\mathrm{P} 40$ per $\mathrm{kg})$

Net income $=$ Gross income - total expenses

\section{CONCLUSION}

This study has investigated two types of cultivation systems and different organic amendments on tomato production to evaluate performance of tomato, determine effectivity to bacterial wilt and assess profitability. The results shown that under structure grown plants had better protection from adverse environmental conditions especially heavy rains, and thus had better performance in terms of lower bacterial wilt infection and weed incidence, higher survival and yield than in the open field. Application of organic amendments to soil regardless of kind increased weight of marketable fruits and total yield than no amendments. Net returns of plants under structure were approximately 8 times higher than in open field with respect to condition of the study and bacterial wilt contamination of site. The use of sunflower amendments gave the highest return under protective structure and wedelia in open field. This study strongly recommends the use of house-type protective structure for tomato production especially in areas with frequent heavy rain as greater probability of safe and quality production, and high yield. Further work needs to be done on organic amendments provided that in this study mortality by bacterial wilt was inevitable. 
Gonzaga et al

\section{ACKNOWLEDGEMENT}

The researchers would like to thank ACIAR for the research funds, to PCAARRD and to everyone who has contributed to this experiment.

\section{REFERENCES}

Abrantes OF JR. 2013. Performance of Grafted and Pruned Tomato (Lycopersicon esculentum Mill.) under Protective Structure and Open Field. (Undergraduate thesis). Visayas State University, Baybay City, Leyte, Philippines

Agustin FT.2007. Evaluating the Biofumigation Potentials of Various Brassica Species for the Control of Ralstonia solanacearum (E.F. Smith) Yabuuchi et al. Affecting Potatoes (Undergraduate thesis). Benguet State University, La Trinidad, Benguet. Retrieved on Nov. 10, 2017 from digilib.bsu.edu.ph/green stone/colle ct/ungra/index/assoc/HASHf237.dir/doc.pdf

Altoveros NC and Borromeo TH. 2007. Country Report on the State of Plant Genetic Resources for Food and Agriculture Philippines. The State of the Plant Genetic Resources for Food and Agriculture of the Philippines (19972006). Retrieved on Nov. 10, 2017 from http.www.fao.org/docrip/013/i1500 e/Philippines.pdf

Ana UR and Sugha SK. 2007. Role of cultural practices in the management of colocasia blight. Plant Disease Research 22(1):30-33

Anith KN, Momol MT, Kloepper JJ, Olson SM \& Jones JB. 2004. Efficacy of plant growth-promoting rhizobacteria, acibenzolar-S-methyl, and soil amendment for integrated management of bacterial wilt on tomato. Plant Disease 88:669673

BAS. 2015. Bureau of Agricultural Statistics. Retrieved on June 28, 2016 http://countrystat.psa.gov.ph/selection.asp

Berg L. 2008. Introductory Botany: Plants, People and the Environment (pp226). Thomson Learning, Inc

Borines LM, Gonzaga ZC, Capuno OB, Gerona RG, Lusanta DC, Dimabuyu HB, Vega MLP \& Rogers GS. 2016. Disease of Commonly Affecting Vegetables in Eastern Visayas, Philippines, and their Incidence under Protective structure and in the open Field. Acta Horticulturae 1128:117-124. doi: 10.17660/Acta Hortic. 1128.16

Brown PD and Morra MJ. 1997. Control of soil-borne plant pests using glucosinolate-containing plants. Advance in Agronomy 61:167-231

Chen JG. 2001. Dual auxin signalling pathways control cell elongation and division. Journal of Plant Growth Regulation 20:255-264

De La Peña RC and Hughes JDA. 2007. Improving vegetable productivity in a variable and changing climate. Retrieved on March 8, 2013

Dimabuyu HB, Gonzaga ZC, Lusanta DC, Mangmang JS, Capuno OB \& Rogers GS. 2016. Reducing Disease Incidence and Increasing Productivity of Ampalaya (Momordica charantia L.) through Pruning and Protected Cultivation. Acta Horticulturae 1128:177-182 . doi:10.17660/ActaHortic.2016.1128.26

Food and Agriculture Organization Corporate Statistical Database (FAOSTAT). 2012. Food and Agriculture Organization of the United Nations. http://faostat.fao.org/site/567/DesktopDefault.aspx?PagelD=567\#ancor. Date retrieved. June 28, 2016 
Growth and yield of tomato

Genin S, Brito B, Denny TP \& Boucher C, 2005. Control of the Ralstonia solanacearum type III secretion system (hrp) genes by the global virulence regulator PhcA. FEBS Letters 579(10):2077-208

Gergon EB, Gapasin R, Opina OS \& Halbrendt JM. 2000. Evaluation of Rice Hull Burning for Management of Rice Root-Knot Nematode in Rice-Onion Cropping System, in Proceedings of the 31st Anniversary Scientific Convention of the Pest Management (pp58-59). 3-6 May 2000, Council of the Philippines, Baguio City

Ghorbani R, Koocheki A, Jahan M \& Asadi GA. 2008. Impact of organic amendments and compost extracts on tomato production and storability in agroecological systems. (Impact of organic amendments and compost extracts on tomato production and storability in agroecological systems. Agronomy for sustainable development (pp307-311). ISSN:1774-0746

Gonzaga ZC, Capuno OB, Loreto MB, Gerona RG, Borines LM, Tulin AT, Mangmang JS, Lusanta DC, Dimabuyu HB \& Rogers GS. 2013. Low-cost protected cultivation: Enhancing year-round production of high-value vegetables in the Philippines. In Oakeshott J and Hall D (eds) Smallholder HOPES- horticulture, people and soil. Proceedings of the ACIAR-PCAARRD Southern Philippines. Fruits and Vegetables Program meeting, 3 July 2012, Cebu, Philippines. ACIAR Proceedings 139 (pp298). Australian Centre for International Agricultural Research: Canberra

Gonzales A and Canto-Saenz MA. 1993. Comparison of five organic amendments for the control of Globodera pallida in microplots in Peru. Nematropica 23:133139

Halim GMA and Islam MS. 2013. Performance of Sweet Pepper under Protective Structure in Gazipur of Bangladesh. International Journal of Environment 1(1):1-8. Retrieved on November 12, 2016 from http://www.nepjol.info/index .php/IJE/article/view/8523

Hayward AC. 1991. Biology and epidemiology of bacterial wilt caused by Ralstonia solanacearum. Annual Review of Phytopathology 29:65-87

Hayward AC. 2000. Ralstonia solanacearum. Encyclopedia of Microbiology 4:32-42 (2nd edn). Academic Press, London, UK

Holopainen JK. 2004. Multiple functions of inducible plant volatiles. Trends in Plant Science 9:529-533

Janvier C, Villeneuve F, Alabouvette C, Edel-Hermann V, Mateille T \& Steinberg C. 2007. Soil health through soil disease suppression: Which strategy from descriptors to indicators?. Soil Biology and Biochemistry 39:1-23

Kimpinski J, Gallant CF, Henry R, Macleod JA, Sanderson JB \& Sturz AV. 2003. Effect of compost and manure soil amendments on nematodes and yields of potato and barley: a 7-year study. Journal of Nematology 35:289-293

Lacostales LE. 2015. Influence of Mulching Materials on the Growth and Yield of Sweet Pepper (Capsicum annum L.) grown in Two Types of Cultivation Systems (MS thesis). Visayas State University, Baybay City, Leyte, Philippines

Lusanta D. 2016. Productivity and Profitability of Tomato (Solanum lycopersicum L.) grown under two types of cultivation system as affected by type of irrigation and mulching practices in Cabintan, Ormoc city. (Unpublished thesis). Department of Horticulture, Visayas State University, Visca, Baybay City, Leyte, Philippines

Norsworthy JK, Brandenberger L, Burgos NR \& Riley M. 2005. Weed suppression in 
Vigna unguiculata with a spring-seeded Brassicaceae green manure. Crop Protection 24:441-447

Ohno TK, Doolan K, Zibilske LM, Liebman M, Gallandt ER \& Berube C. 2000. Phytotoxic effects of red clover amended soils on wild mustard seeding growth. Agriculture, Ecosystems \& Environment 78(2):187-192

$\mathrm{Om} \mathrm{H}$, Dhiman S, Kumar S \& Kumar H. 2002. Allelopathic response of Phalaris minor to crop and weed plants in rice-wheat system. Crop Protection 21:699-705

Obi ME and Ebo P. 1995. The effect of organic and inorganic amendments on soil physical properties and production in a severely degraded sandy soil in southern Nigeria. Bioresource- Technology 51(2-3):117-123

Rylski I and Spigelman M. 1986. Effect of shading on plant development, yield and fruit quality of sweet pepper grown under conditions of high temperature and radiation. Scientia Horticulturae 29(1-2):31-35

Sreenivasa MN, Nagaraj MN \& Bhat SN. 2010. Beejamruth: A source for beneficial bacteria. Karnataka Journal of Agricultural Science 17(3):72-77

Sumalinog RR. 2015. Influence of Different Organic and Colored Plastic Mulches on the Growth and Yield of Tomato (Solanum lycopersicum L.) grown in the Open Field and Protective Structure (MS thesis). Visayas State University, Baybay City, Leyte, Philippines

Tuyan WO. 2015. Growth and Yield of Bitter Gourd (Momordica charantia L.) as Influenced by Organic and Colored Plastic Mulches under Two Types of Cultivation System (MS thesis). Visayas State University, Leyte, Philippines

Song Z, Gao H, Zhu P, Peng C, Deng A, Zheng C, Mannaf MA, Islam MN \& Zhang W. 2015. Organic amendments increase corn yield by enhancing soil resilience to climate change. Institute of Crop Sciences, Chinese Academy of Agricultural Sciences/Key Laboratory of Crop Physiology and Ecology, Ministry of Agriculture, Beijing 100081, China. The Crop Journal 3(2):110-117. https://doi.org/10.1016/j.cj.2015.01.004 